\title{
1 Performance and kinetic modelling of photolytic and \\ 2 photocatalytic ozonation for enhanced micropollutants removal \\ 3 in municipal wastewaters
}

4

5 Danilo Bertagna Silva, Alberto Cruz-Alcalde, Carmen Sans, Jaime Giménez*, Santiago

6 Esplugas

7 Department of Chemical Engineering and Analytical Chemistry, Faculty of Chemistry,

8 Universitat de Barcelona, C/Martí i Franqués 1, 08028 Barcelona, Spain

*Corresponding Author: Jaime Gimenez, j.gimenez@ub.edu

\section{ABSTRACT}

In this work, the performances of ozonation, photolytic ozonation (UV-C/O3), and

photocatalytic ozonation $\left(\mathrm{UV}-\mathrm{A} / \mathrm{TiO}_{2} / \mathrm{O}_{3}\right)$ in degrading ozone recalcitrant

micropollutants in four different real domestic wastewaters were evaluated in semi-

continuous operation, together with the influence of water matrices in the ozone mass

transfer and pollutant degradation rates. The $\bullet \mathrm{OH}$ exposure per consumed ozone ratio, defined as $\mathrm{RoH,O3,} \mathrm{was} \mathrm{applied} \mathrm{for} \mathrm{single} \mathrm{ozonation} \mathrm{and} \mathrm{modified} \mathrm{for} \mathrm{light-assisted}$ ozonation processes to evaluate and compare the contribution of radical pathway on micropollutants abatement for the different wastewaters studied. RoH,O3 plots presented good fitting $\left(\mathrm{R}^{2}>0.95\right)$ in two stages, corresponding to different ozone mass transfer regimes, for all cases. Light-assisted ozonation attained higher pollutant degradation for 
all water matrices compared to single ozonation, although the performance of UVassisted processes was more sensitive to matrix factors like composition and turbidity. Moreover, the improvement brought by both light-based processes on Rоно3 values mainly took place during the second stage. Thus, photocatalytic ozonation reached Rоноз values higher than double for all wastewaters, compared with single ozonation (between $105 \%$ and $127 \%$ increase). These values represent a saving of almost half of the overall ozone needs (42\%) for the same ozone recalcitrant micropollutant depletion, although it would require the adoption of higher ozone doses than the currently employed for ozonation in wastewater treatment plants.

\section{KEYWORDS}

Wastewater ozonation; UV light; photocatalysis; advanced oxidation processes; recalcitrant micropollutants.

\section{Introduction}

The ever-growing development, production and consumption of new chemical substances have raised the need of developing new technologies for wastewater treatment because many of these substances show a bio-accumulative and non-biodegradable character, persisting in the environment [1]. These substances are commonly called micropollutants (MP) because their presence on water bodies and wastewater treatment plants (WWTP) effluents ranges from nano $\left(n g \mathrm{~L}^{-1}\right)$ to micro $\left(\mu \mathrm{g} \mathrm{L}^{-1}\right)$ scale $[2,3]$. Their presence in the aquatic environment is associated to a variety of negative effects, including short and long-term toxicity, endocrine disruption and antibiotic resistance in microorganisms [4,5]. 

wastewater treatment, with demonstrated performance by many studies from laboratory to full scale $[6,7,8]$. The quick decomposition of ozone leaves no traces of its presence in water, unlike chlorine. However, ozone is a selective oxidant. Second-order rate constants for ozone vary several orders of magnitude, between $<0.1 \mathrm{M} \mathrm{s}^{-1}$ and $7 \times 10^{9} \mathrm{M}$ $\mathrm{s}^{-1}[9]$. Due to its high production costs, ozone doses typically employed are relatively low: TOD/DOC (transferred ozone dose/dissolved organic carbon) ratios range between 0.5 and $1.5[10]$.

The stress caused by global water scarcity has been increasing demands of wastewater reuse for direct human consumption [11]. Therefore, higher purity standards have to be attained to eliminate all pollutants and allow a safe use of water. Higher $\mathrm{O}_{3}$ doses can be a way of reaching this goal, because the natural decomposition of ozone generates hydroxyl radicals $(\bullet \mathrm{OH})$ in non-acidic pHs (equations 1 and 2$)$. These radicals have a higher oxidation potential than ozone and they are non-selective oxidants, being able to oxidize many molecules that ozone cannot. Therefore, this is an interesting option accounting for the sum of molecular ozone and hydroxyl radicals contribution [13]. There is a considerable number of data on kinetic constants of pollutants reactions with molecular ozone and the hydroxyl radical $[14,15]$, being those for hydroxyl radical in the

Degradation of a micropollutant during ozonation can be described by equation 3, range of $10^{9}-10^{10} \mathrm{M} \mathrm{s}^{-1}$ for most of micropollutants. 


$$
-\ln \left(\frac{[M P]}{[M P]_{0}}\right)=k_{M P, O_{3}} \int\left[O_{3}\right] d t+k_{M P, O H} \cdot \int[O H \cdot] d t
$$

Ultra-violet light is commonly adopted on wastewater treatment plants for disinfection [16]. Many pollutants and cell membranes of microorganisms undergo photolysis. Their degradation rates vary with light intensity and wavelength, matrix composition and geometry of the reactor [17].

Ozone absorbs light at UV-C range, presenting a peak value at wavelength of 254 $\mathrm{nm}$ [12]. Equations 4-6 show the formation of hydroxyl radicals under these circumstances [18], creating a highly oxidative medium in a process called photolytic ozonation.

$$
\begin{aligned}
\mathrm{O}_{3}+\mathrm{H}_{2} \mathrm{O} & \stackrel{h v}{\rightarrow} \mathrm{O}_{2}+\mathrm{H}_{2} \mathrm{O}_{2} \\
\mathrm{H}_{2} \mathrm{O}_{2} & \stackrel{h v}{\rightarrow} 2 \mathrm{OH} \cdot \\
2 \mathrm{O}_{3}+\mathrm{H}_{2} \mathrm{O}_{2} & \rightarrow 2 \mathrm{OH} \cdot+3 \mathrm{O}_{2}
\end{aligned}
$$

Besides contributing on radical formation, when UV light is included in the system, a first-order degradation rate photolysis of a target micropollutant should be accounted on the equation describing its abatement [18] (Eq. 7).

$$
-\ln \left(\frac{[M P]}{[M P]_{0}}\right)=k_{M P, O_{3}} \int\left[O_{3}\right] d t+k_{M P, O H} \int[O H \cdot] d t+k_{M P, U V} \int d t
$$

The high photocatalytic activity of $\mathrm{TiO}_{2}$ and some of its properties (economical, non-toxic, insoluble and stable in water [19]) make it a substance of great interest for wastewater treatment and recalcitrant pollutants abatement. With a band gap between 3.0 and $3.2 \mathrm{eV}$ (UV-A, near visible), electrons on its valence band $\left(\mathrm{evvb}^{-}\right)$can be promoted to conduction band $\left(\mathrm{ecb}^{-}\right)$, generating a reactive electron-hole pair when irradiated by UV light [20]. This pair can go back to its original place or engage in oxidation reactions with 
the surrounding medium. In wastewater matrices, this can generate hydroxyl radicals and contribute to micropollutants abatement [21, 22].

Ozonation and photocatalysis can be combined to attain a higher degree of pollutant degradation in a process called photocatalytic ozonation. Ozone reacts with the conductive-band electron, thus preventing its return to the valence band, and forms ozonide radicals $\left(\mathrm{O}_{3}{ }^{-}\right)$, an initial step towards the formation of more hydroxyl radicals in this system, shown by equations 8 and 9 [23, 24, 25]. The degradation efficiency of photocatalytic ozonation has been demonstrated in many lab-scale studies [26, 27, 28, 29, 30], but few of them have been performed on real wastewaters [31, 32].

$$
\begin{array}{r}
\mathrm{O}_{3}+\mathrm{e}^{-} \rightarrow \mathrm{O}_{3}^{-} \cdot \\
\mathrm{O}_{3}^{-}+\mathrm{H}_{2} \mathrm{O} \rightarrow \mathrm{O}_{2}+\mathrm{OH}^{-}+\mathrm{OH}^{\circ} .
\end{array}
$$

The control of micropollutants removal and the optimization of the required ozone dose during the process are still unaccomplished challenges. One of the most common difficulties is the impossibility of directly measuring the hydroxyl radical concentration, due to its nearly instantaneous reaction rates [33, 34]. Attempts to work around this problem were made by the development of the recent Rоноз concept, which is a valuable step towards the prediction of pollutant abatement in ozonation processes [35]. The Rоноз concept is defined as the hydroxyl radical exposure per transferred ozone dosage (equation 10).

$$
R_{\mathrm{OHO}_{3}}=\frac{\int[\mathrm{OH} \cdot] d t}{T O D_{t}}
$$

The $\bullet \mathrm{OH}$ exposure can be obtained through the monitoring of a probe compound with $\mathrm{k}_{\mathrm{MP}, \mathrm{O} 3}<10 \mathrm{M}^{-1} \mathrm{~s}^{-1}$ [37]. For those ozone-resistant substances, substituting equation 
11510 on equation 7 results in equation 11, that can be used to predict pollutant degradation 116 [36]:

$$
-\ln \left(\frac{[M P]_{t}}{[M P]_{0}}\right)=k_{M P, O H} * R_{O H, O_{3}} * T O D_{t}
$$

The goals of this study were: 1 ) to compare the performance of single, photolytic and photocatalytic removal of ozone-resistant micropollutants in real municipal wastewaters coming from different sources and processes, thus having very different compositions; 2) to adapt and check the utility of the Rоноз concept in the modelling of these ozone-based processes; 3) to evaluate the influence of light and catalyst on the ozonation of different real domestic wastewaters trough the Rоноз parameter.

Acetamiprid (ACMP) and atrazine (ATZ) analytical standards were acquired from in Gavà and El Prat (Barcelona, Spain). Two of them came from Gavà station (MBR outlet of a membrane bioreactor, MBBR - outlet of a moving bed biofilm reactor) and the other two came from El Prat station (CAS - conventional activated sludge, CAS-DN 
gathered in Table 1. (TOC: total organic carbon; COD: chemical oxygen demand; UV254: specific absorbance at $254 \mathrm{~nm}$ ) All the effluent samples were filtered with conventional filter paper, to remove coarse particles, and stored at $4{ }^{\circ} \mathrm{C}$ prior to use.

Table 1. Effluent characterization

\begin{tabular}{cccccccc}
\hline $\begin{array}{c}\text { Wastewater } \\
\text { ID }\end{array}$ & $\mathbf{p H}$ & $\begin{array}{c}\text { Turbidity } \\
\text { [NTU] }\end{array}$ & $\begin{array}{c}\text { TOC } \\
{\left[\mathbf{m g ~ C ~ L}^{-1}\right]}\end{array}$ & $\begin{array}{c}\mathbf{C O D} \\
{\left[\mathbf{m g ~ O}_{2} \mathbf{~ L}^{-1}\right]}\end{array}$ & $\begin{array}{c}\mathbf{U V}_{254} \\
{\left[\mathbf{m}^{-1}\right]}\end{array}$ & $\begin{array}{c}\text { DOC } \\
{\left[\mathbf{m g ~ C ~ L ~}^{-1}\right]}\end{array}$ & $\begin{array}{c}\text { Alkalinity } \\
{\left[\mathbf{m g ~ C a C O}_{3} \mathbf{~ L}^{-1}\right]}\end{array}$ \\
\hline MBR & 7.7 & 0.5 & 13.6 & 14.9 & 17.4 & 13.3 & 208 \\
CAS-DN & 7.5 & 2.6 & 13.2 & 27.3 & 24.6 & 13.4 & 275 \\
CAS & 8.0 & 20.1 & 37.8 & 70.5 & 48.9 & 18.7 & 449 \\
MBBR & 7.8 & 18.5 & 51.1 & 71.3 & 50.3 & 21.7 & 469 \\
\hline
\end{tabular}

142

\subsection{Single and light assisted ozonation experiments}

Ozone was produced from pure oxygen by a 301.19 lab ozonizer (Sander, Germany). The ozonation of wastewaters was performed in a $1.5 \mathrm{~L}$ jacketed reactor covered with aluminum foil, to avoid radiation losses, and operated in semi-continuous mode. Ozone was injected at the bottom of the reactor by a porous diffuser. A magnetic stirrer ensured the good contact between liquid and gas phases and a homogeneous liquid phase. Experiments were performed at $22 \pm 2{ }^{\circ} \mathrm{C}$. The gas flow rate was maintained at 0.3 $\mathrm{L} \mathrm{min}^{-1}$ and the inlet concentration of ozone at $10 \mathrm{mg} \mathrm{L}^{-1}$ (values at STP conditions). Gasphase ozone concentrations were continuously monitored by two BMT 964 ozone analyzers (BMT Messtechnik, Germany) placed on the reactor inlet and outlet. The ozone concentration in the liquid phase was measured by a Q45H/64 dissolved $\mathrm{O}_{3}$ probe (Analytical Technology, USA), which was connected to a liquid recirculation stream. For experiments with $\mathrm{TiO}_{2}$, the dissolved ozone was not measured to preserve the equipment's probe membranes from small solid particles. 
A detailed scheme of the ozonation setup is shown elsewhere [36].

For experiments assisted by UV radiation, two different reactor configurations were employed. In experiments with UV-C radiation, a single lamp (4W, $254 \mathrm{~nm}$, Phillips) with a photon fluence rate of $1.01 \mathrm{~mW} \mathrm{~cm}^{-2}$ (obtained by atrazine's actinometry [37]) was used. For experiments with UV-A light, three black light bulb (BLB) lamps (Philips TL 8 W-08 FAM) of 8 W each with a wavelength range 350-400 nm (maximum at $365 \mathrm{~nm}$ ) and a fluence rate of $5.47 \mathrm{~mW} \mathrm{~cm}^{-2}$ were used instead. In both cases, the lamps

All experiments ran for one hour. ACMP was used as $\bullet \mathrm{OH}$ probe compound, since it is an $\mathrm{O}_{3}$-resistant micropollutant $\left(k_{A C M P, O 3}=0.25 \mathrm{M}^{-1} \mathrm{~s}^{-1}\right.$ and $k_{A C M P,} \cdot \mathrm{OH}=2.1 \cdot 10^{9} \mathrm{M}^{-1} \mathrm{~s}^{-}$ ${ }^{1}$ ) [39]. The spiked concentration of ACMP in all effluents was $100 \mu \mathrm{g} \mathrm{L}{ }^{-1}$. Samples were withdrawn at known time intervals and kept at room conditions until complete consumption of dissolved ozone was achieved.

UV [39]. Prior to the analysis, samples were filtered using $0.45 \mu \mathrm{m}$ PVDF syringe filters. 
All different ozonation processes and the corresponding blank experiments were also performed on Milli-Q water buffered with a pH 7 phosphate solution (1 M). The results can be found on the Supplementary Information, Figs. S1 and S2.

\section{Results and discussion}

\subsection{Ozone mass transfer and ozone demand}

Ozone mass balance and demand could be assessed through continuously monitoring inlet and outlet (gas phase) ozone concentrations, as well as dissolved (liquid phase) ozone (Figs. S3-S7). Clearly, two kinetic regimes could be discerned: initially, ozone mass transfer was very fast, attaining a $\eta_{\text {tr }}$ value (slope of transferred versus applied ozone doses plot) above 0.8 for all matrices and processes (see Table 2 and Fig. S8 on the SI). During the first stage, all wastewaters contained substances that are highly reactive with ozone, consuming it faster. In the second stage, encompassing the last 30 minutes of experiment, the transfer yield decreased because it got controlled by moderate or slow ozone rate reactions [12] and it was possible to discern the influence of different matrices: wastewaters with a higher organic and inorganic carbon content (CAS and MBBR) had higher ozone transfer yields.

When UV-C light was turned on, the $\eta_{\text {tr }}$ value increased for all wastewaters in the second stage. UV-C light accelerates ozone depletion (equation 4) leading to less ozone leaving the system, thus optimizing the transfer yield for all cases. Ozone transfer yield increase was higher for less turbid matrices, Milli-Q, MBR and CAS-DN, due to the better UV-C radiation transmission on these media.

When UV-A was added to $\mathrm{TiO}_{2}$ experiments, ozone mass transfer of the Milli-Q, MBR and CAS-DN matrices improved considerably. Less turbidity and lower organic 
matter content (see table 1) allowed more photon absorption by $\mathrm{TiO}_{2}$, leading to a higher $\mathrm{e}^{-}$cb production. Equation 8 shows how this may lead to additional ozone consumption in the system.

Table 2 also includes the instantaneous ozone demand (IOD) and the pseudo-first order decay rate of ozone $(\mathrm{kd})$ values obtained for ozonation (for definition and calculation methods see Text S1). Values for photolytic ozonation were not obtained because no ozone was detected in the liquid phase during those experiments due to the efficient ozone decomposition under those integrated systems. IOD describes the ozone demand when it is instantaneously consumed by the wastewater, and consequently represents the dose of ozone at the point of the transition between primary (fast) and secondary (slow) ozonation stages [38]. As it is expected, more polluted matrices had higher IODs. For real wastewaters, an IOD/DOC ratio of approximately $1.0 \pm 0.1$ was obtained for all wastewaters tested. Milli-Q water presented two phases and IOD value of $4 \mathrm{mg} / \mathrm{L}$ due to the ACMP addition.

$k_{d}$ values were higher for more polluted water, but since the TOC value of MBR and CAS-DN are similar, the latter had a slower $\mathrm{O}_{3}$ decomposition due to its higher alkalinity content [40].

(1)

Table 2: $\mathrm{O}_{3}$ mass transfer, IOD and $\mathrm{k}_{\mathrm{d}}$ for all studied waters. All $\mathrm{R}^{2}>0.99$

\begin{tabular}{|c|c|c|c|c|c|}
\hline \multirow{2}{*}{ Process } & \multirow{2}{*}{$\begin{array}{l}\text { MATRIX } \\
\text { ID }\end{array}$} & \multicolumn{2}{|c|}{$\eta_{\text {tr }}\left[\right.$ trans. $\left.\mathrm{O}_{3} / \mathrm{app} . \mathrm{O}_{3}\right]$} & \multirow{2}{*}{$\mathrm{IOD}\left[\mathrm{mgO}_{3} \mathrm{~L}^{-1}\right]$} & \multirow{2}{*}{$\mathrm{k}_{\mathrm{d}}\left[\mathrm{min}^{-1}\right]$} \\
\hline & & Stage 1 & Stage 2 & & \\
\hline Ozonation & \multirow{4}{*}{ Milli-Q } & 0.86 & 0.14 & 4 & 0.10 \\
\hline $\mathrm{UV}-\mathrm{C} / \mathrm{O}_{3}$ & & 0.90 & 0.40 & - & - \\
\hline $\mathrm{TiO}_{2} / \mathrm{O}_{3}$ & & 0.89 & 0.04 & & \\
\hline $\mathrm{TiO}_{2} / \mathrm{UV}-\mathrm{A} / \mathrm{O}_{3}$ & & 0.87 & 0.40 & & \\
\hline Ozonation & MBR & 0.82 & 0.17 & 12 & 0.14 \\
\hline
\end{tabular}




\begin{tabular}{cccccc}
\hline $\mathrm{UV}-\mathrm{C} / \mathrm{O}_{3}$ & & 0.82 & 0.37 & - & - \\
$\mathrm{TiO}_{2} / \mathrm{O}_{3}$ & & 0.87 & 0.14 & & \\
$\mathrm{TiO}_{2} / \mathrm{UV}-\mathrm{A} / \mathrm{O}_{3}$ & & 0.83 & 0.35 & & 0.05 \\
\hline Ozonation & & 0.88 & 0.17 & 15 & - \\
$\mathrm{UV}-\mathrm{C} / \mathrm{O}_{3}$ & $\mathrm{CAS}-\mathrm{DN}$ & 0.91 & 0.41 & - & \\
$\mathrm{TiO}_{2} / \mathrm{O}_{3}$ & & 0.82 & 0.20 & & 0.29 \\
$\mathrm{TiO}_{2} / \mathrm{UV}-\mathrm{A} / \mathrm{O}_{3}$ & & 0.80 & 0.29 & & - \\
\hline $\mathrm{Ozonation}$ & & 0.85 & 0.30 & 18 & \\
$\mathrm{UV}-\mathrm{C} / \mathrm{O}_{3}$ & $\mathrm{CAS}$ & 0.89 & 0.44 & - & - \\
$\mathrm{TiO}_{2} / \mathrm{O}_{3}$ & & 0.88 & 0.27 & & \\
$\mathrm{TiO}_{2} / \mathrm{UV}-\mathrm{A} / \mathrm{O}_{3}$ & & 0.83 & 0.30 & & \\
\hline $\mathrm{Ozonation}$ & & 0.88 & 0.31 & 25 & - \\
$\mathrm{UV}-\mathrm{C} / \mathrm{O}_{3}$ & $\mathrm{MBBR}$ & 0.94 & 0.37 & - & \\
$\mathrm{TiO}_{2} / \mathrm{O}_{3}$ & & 0.95 & 0.27 & & \\
$\mathrm{TiO}_{2} / \mathrm{UV}-\mathrm{A} / \mathrm{O}_{3}$ & & 0.85 & 0.28 & & \\
\hline
\end{tabular}

227 photocatalysis were performed to verify their contribution on photocatalytic ozonation.

228 ACMP did not show any degradation due to UV-A photolysis, and $\mathrm{UV}-\mathrm{A} / \mathrm{TiO} 2$

229 photocatalysis presented little degradation for the MBR effluent sample (less than 6\%) 230 and no degradation for all the other wastewaters (figure S9 of the supplementary 231 information). ACMP degradation by UV-C radiation ranked from $45 \%$ for MBBR up to $60 \%$ for MBR, increasing with the decrease of organic matter content and turbidity of wastewater (Figure S10).

Figure 1 shows degradation of ACMP for single, photolytic (UV-C), photocatalytic (UV-A/TiO 2$)$ and catalytic $\left(\mathrm{TiO}_{2}\right)$ ozonation in all matrices tested, at different TOD/DOC ratios. Figure S11 shows the same degradation per reaction time (60 237 minutes). 

degradations above $90 \%$ for all matrices. Photocatalytic ozonation was the most matrixinfluenced process: MBR matrix reached 100\% of ACMP final degradation - being the highest of all the experiments - but this value dropped on each of the other matrices: final

244 degradation in CAS-DN was 93\% and in CAS and MBBR, 89\%. As more organic matter 245 adsorbed on the catalyst surface hinders its photo-activity, photocatalytic ozonation efficiency decreases. Moreover, turbid matrices also hinder photo-activity, as well as the presence of dissolved UV-absorbent organic species, thus decreasing the amount of photons reaching the catalyst surface.
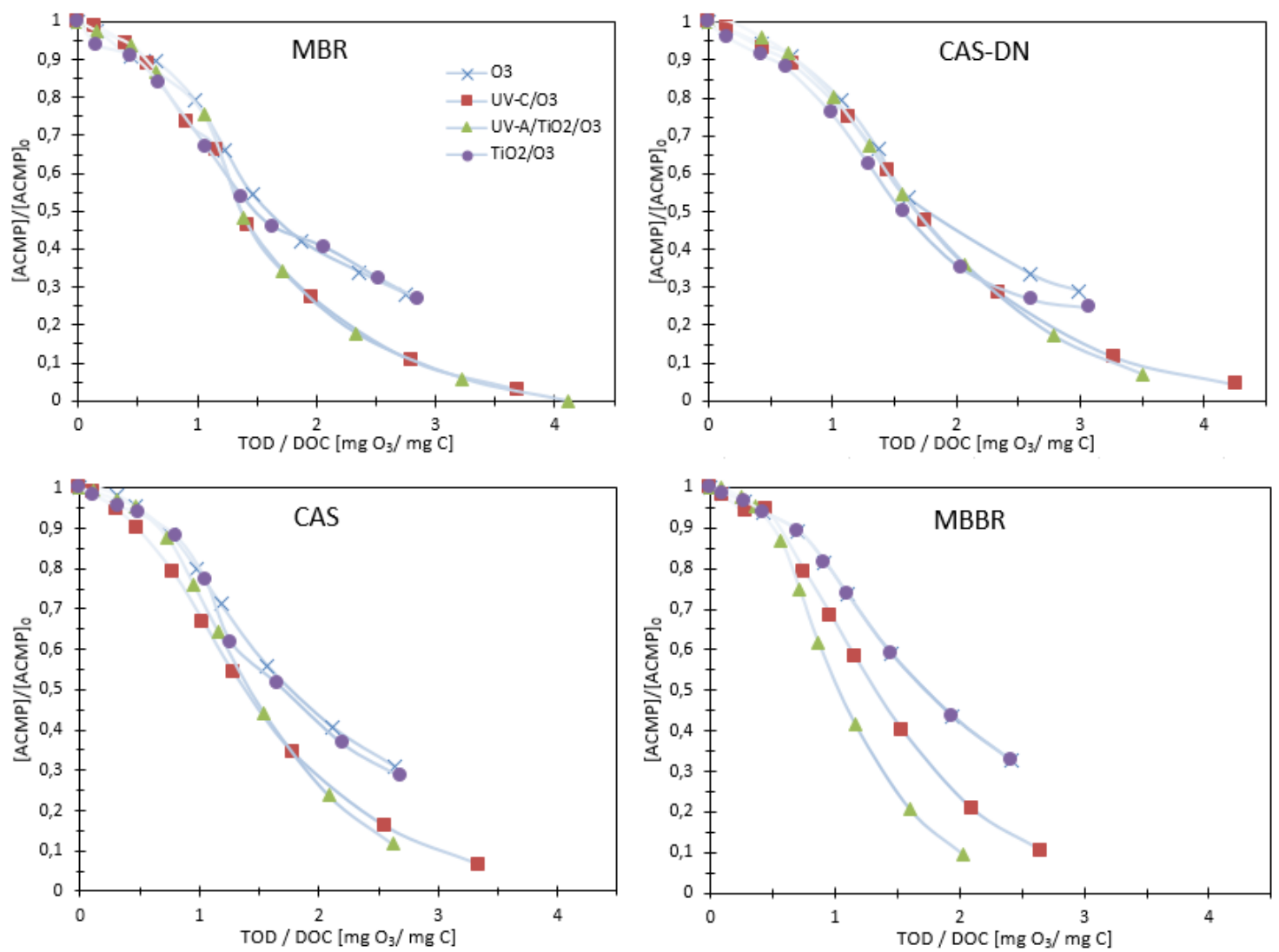

250 Figure 1. ACMP degradation per TOD/DOC 0 ratio for all studied wastewaters. Gas flow rate $=0.3 \mathrm{~L}$ $\min ^{-1}$; Inlet (g) ozone concentration $=10 \mathrm{mg} \mathrm{O}_{3} \mathrm{~L}^{-1} ; \mathrm{T}_{\text {reaction }}=20 \pm 2{ }^{\circ} \mathrm{C}$; $\mathrm{T}_{\text {in }}$ (gas) $=22 \pm 2{ }^{\circ} \mathrm{C}$; $\mathrm{P}_{\text {in }}$ (gas) $=$ $25 \pm 2$ mbar. 

to improve its effectiveness compared with single ozonation or $\mathrm{TiO}_{2} / \mathrm{O}_{3}$ at different TOD/COD values. The cleaner matrices MBR and CAS-DN required a TOD/DOC ratio of about 1.5, much higher than currently employed ratios for these types of waters (from 0.5 up to 1). This can be related to the two-stage character of the process: initially, reactivity between $\mathrm{O}_{3}$ and matrix compounds is very high, hindering radical production with or without light. During second stage, quick $\mathrm{O}_{3}$ reactions are less prominent and radical formation paths are favored. Moreover, a decrease in turbidity during ozonation would have allowed more photons to reach $\mathrm{O}_{3}$ or $\mathrm{TiO}_{2}$ molecules, promoting the radical pathway as well. This means that, in order to improve ozone-resistant micropollutants removal by light assisted processes, the employed ozone doses should also increase. In return, the ozone doses required to reach satisfactory degradation levels of recalcitrant micropollutants will be reduced due to the increase of $\bullet \mathrm{OH}$-exposure provided by light MBBR clearly improved the overall AMCP degradation efficiency from lower TOD/DOC ratios of 1.2 and 0.6 , respectively. That is, improvement of $\bullet \mathrm{OH}$-exposure provided by light assisted processes were assessed at TOD/COD ratios closer to currently employed ones. Still, due to high organic content and alkalinity of these types of wastewaters, the TOD/DOC needed for recalcitrant micropollutants abatement and consequently the required ozone doses would be much higher. Thus, in the case of $65 \%$ 
2.2 in single ozonation to 1.7 for light assisted processes in CAS effluent, while for MBBR wastewater, this ratio dropped from 2.4 down to 1.7 for photolysis and to 1.3 for photocatalytic ozonation. The latter represents a saving of almost half of the overall ozone needs (42\%) for the same micropollutant degree of depletion.

\subsection{Rоно3 determination}

In this work, the recalcitrant pesticide acetamiprid was used as model compound for Rоноз estimation during wastewater ozonation. UV-C photolysis blank tests were carried out for all wastewaters to quantify their contribution on ACMP degradation during photolytic ozonation (equation 7). The first-order degradation rate $k_{M P, U V}$ obtained for each matrix was used to deduct the amount of hydroxyl radical exposure at each reaction time t, according to equation 12. During ozonation the matrices undergo several changes, and it can be a source of error on degradation rate determination [12]. Being so, it is not possible to determine separately how much of acetamiprid degradation is due to direct photolysis and how much to the oxidation by the hydroxyl radical. Thus, factors affecting photolysis were considered constant for all experiments and included in the $k_{M P, U V}$ value.

$$
\int[O H \cdot] d t=\frac{\ln \left(\frac{[M P]_{t}}{[M P]_{0}}\right)+k_{M P, U V} * t}{-k_{M P, O H}}
$$

Data of $\bullet \mathrm{OH}$ exposure per consumed ozone dose fitted to linear model according to equation $10\left(\mathrm{R}^{2}>0.95\right)$, obtaining Rоноз values for all water matrices. These are shown on table 3 , and their plots are given on figure 2. 
Table 3. $\mathrm{R}_{\mathrm{OHO}}$ values for plots on figure 2 and TOD to $65 \%$ of ACMP degradation. All $\mathrm{R}^{2}>0.95$

\begin{tabular}{|c|c|c|c|c|}
\hline \multirow{2}{*}{ Process } & \multirow{2}{*}{ WASTEWATER ID } & \multicolumn{2}{|c|}{$\mathrm{R}_{\mathrm{OHO}}\left[10^{7} \mathrm{~s}^{-1}\right]$} & \multirow{2}{*}{$\begin{array}{l}\text { TOD АСмP 65\% } \\
{\left[\mathrm{mg} \mathrm{O}_{3} \mathrm{~L}^{-1}\right]}\end{array}$} \\
\hline & & S1 & S2 & \\
\hline Ozonation & \multirow{4}{*}{ MBR } & 3.9 & 8.9 & 30 \\
\hline $\mathrm{UV}-\mathrm{C} / \mathrm{O}_{3}$ & & 1.6 & 16.0 & 22 \\
\hline $\mathrm{TiO}_{2} / \mathrm{O}_{3}$ & & 4.1 & 9.0 & 31 \\
\hline $\mathrm{UV}-\mathrm{A} / \mathrm{TiO}_{2} / \mathrm{O}_{3}$ & & 5.1 & 19.7 & 22 \\
\hline Ozonation & \multirow{4}{*}{ CAS-DN } & 2.5 & 8.5 & 34 \\
\hline $\mathrm{UV}-\mathrm{C} / \mathrm{O}_{3}$ & & 1.6 & 12.8 & 28 \\
\hline $\mathrm{TiO}_{2} / \mathrm{O}_{3}$ & & 3.4 & 9.1 & 29 \\
\hline $\mathrm{UV}-\mathrm{A} / \mathrm{TIO}_{2} / \mathrm{O}_{3}$ & & 4.5 & 17.4 & 28 \\
\hline Ozonation & \multirow{4}{*}{ CAS } & 2.4 & 7.0 & 45 \\
\hline $\mathrm{UV}-\mathrm{C} / \mathrm{O}_{3}$ & & 1.7 & 9.6 & 33 \\
\hline $\mathrm{TiO}_{2} / \mathrm{O}_{3}$ & & 1.5 & 7.2 & 43 \\
\hline $\mathrm{UV}-\mathrm{A} / \mathrm{TiO}_{2} / \mathrm{O}_{3}$ & & 1.4 & 14.3 & 33 \\
\hline Ozonation & \multirow{4}{*}{ MBBR } & 1.7 & 6.5 & 50 \\
\hline $\mathrm{UV}-\mathrm{C} / \mathrm{O}_{3}$ & & 1.2 & 9.3 & 35 \\
\hline $\mathrm{TiO}_{2} / \mathrm{O}_{3}$ & & 0.8 & 7.2 & 53 \\
\hline $\mathrm{UV}-\mathrm{A} / \mathrm{TiO}_{2} / \mathrm{O}_{3}$ & & 1.8 & 14.8 & 29 \\
\hline
\end{tabular}

301 for all tests, corresponding to the two ozone transfer rates previously observed, and two Rоноз values were fitted for each stage. Stage 2 values were higher than stage 1 for all cases. In stage 2, the slower molecular ozone consumption by the matrix allows more radical formation per transferred ozone by the different mechanism involved in the processes, increasing the Rоноз, as previously discussed.

By comparing Rоноз it was possible to verify the matrix influence on radical production: waters with higher alkalinity and organic carbon content had smaller Roноз values because many organic substances, bicarbonates and carbonates ions are well known radical scavengers [41, 42]. latter presented smaller values for stage 1 for all matrices. This can be explained by the hypothesis of a too low concentration of the peroxide generated intermediate. On stage 1 
only a small amount of ozone is available for photolysis due to its quick reactivity with the medium, generating a small amount of peroxide (equation 4). While ozone has a high absorptivity at $254 \mathrm{~nm}$ in both liquid $\left(3300 \mathrm{M}^{-1} \mathrm{~cm}^{-1}\right)$ and gas $\left(2950 \mathrm{M}^{-1} \mathrm{~cm}^{-1}\right)$ phases [12], peroxide absorbs at a much lower rate $\left(19 \mathrm{M}^{-1} \mathrm{~cm}^{-1}\right)$ [43]. The efficiency of its photolysis (equation 5, the final step for radical generation) has been reported to be considerably impaired by the presence of pollutants found on wastewaters, especially for small peroxide concentrations [43, 44]. The consequence is that, for stage 1 , ozone is being photolyzed (more ozone is being transferred) but less hydroxyl radicals are being formed. Photolysis of ozone reduces the $\mathrm{O}_{3}$ available for reactions of equations 1 and 2, thus decreasing the hydroxyl radical production and the Rоноз value in comparison to single ozonation. In addition, there is possibly an overestimation of the initial rate of ACMP degradation via direct photolysis, resulting in an underestimation of the total hydroxyl radical exposure value (equation 12). The degradation rate of ACMP was obtained for each matrix in a blank experiment without ozone flow, using only UV light. Since ozone strongly absorbs UV at the $254 \mathrm{~nm}$ wavelength [45], less photons reached ACMP, producing lower degradation by that route. During stage 2, the turbidity of the medium and the ozone's reactivity with the matrices has been reduced. Consequently, more ozone is available for photolysis, thus increasing peroxide formation and consequently $\bullet \mathrm{OH}$ generation (equation 5 and 6). Stage 2 Rоноз values for $\mathrm{UV}-\mathrm{C} / \mathrm{O}_{3}$ experiments were much higher than in single ozonation for all wastewaters ( $80 \%$ for MBR, 51\% for CAS-DN; $37 \%$ for CAS and $43 \%$ for MBBR) indicating the expected increase on hydroxyl radical exposure per ozone consumed and the overall efficiency improvement of photolytic ozonation.

When $\mathrm{TiO}_{2}$ is added to ozonation, stage 2 Rоноз values increased slightly for all cases, while stage 1 value decreased for more polluted matrices CAS and MBBR. The 
understanding of this is limited due to the lack of data regarding heterogeneous catalytic ozonation performed in highly polluted wastewaters and the multiple interactions that might be taking place between light, ozone, the catalyst and the matrix. However, possible hypothesis is that the presence of $\mathrm{TiO}_{2}$ may change the reactivity of molecular ozone with

344 the matrix, thus affecting the Rоноз value. Further studied should be performed in this 345 direction.

The effect of photocatalytic ozonation on Rоноз values was also much more significant during second stage. Stage 2 Rоноз values for photocatalytic ozonation were the highest of all assayed processes- which can be explained by the multiple radical

349 formation routes provided by the synergistic effect of ozonation and heterogeneous photocatalysis combined [23]. Thus, stage 2 Rоноз values reached values higher than double for all wastewaters, compared with single ozonation (105\% increase in CAs-DN and CAS; $121 \%$ increase in MBR and $127 \%$ increase in most polluted wastewater MBBR). These values confirm the importance of phtotocatalytic process on promoting the radical pathway in ozonation. On the other hand, stage 1 values for less turbid waters MBR and CAS-DN were higher than on single ozonation, most probably due to the smaller effect of organic matter and higher light absorption by $\mathrm{TiO}_{2}$.

Table 3 also shows the amount of TOD needed to reach $65 \%$ of ACMP degradation for each process and matrix. As expected, less polluted matrices and lightassisted ozonation processes attaining higher Rоноз needed less transferred ozone in general to reach this degradation value. 

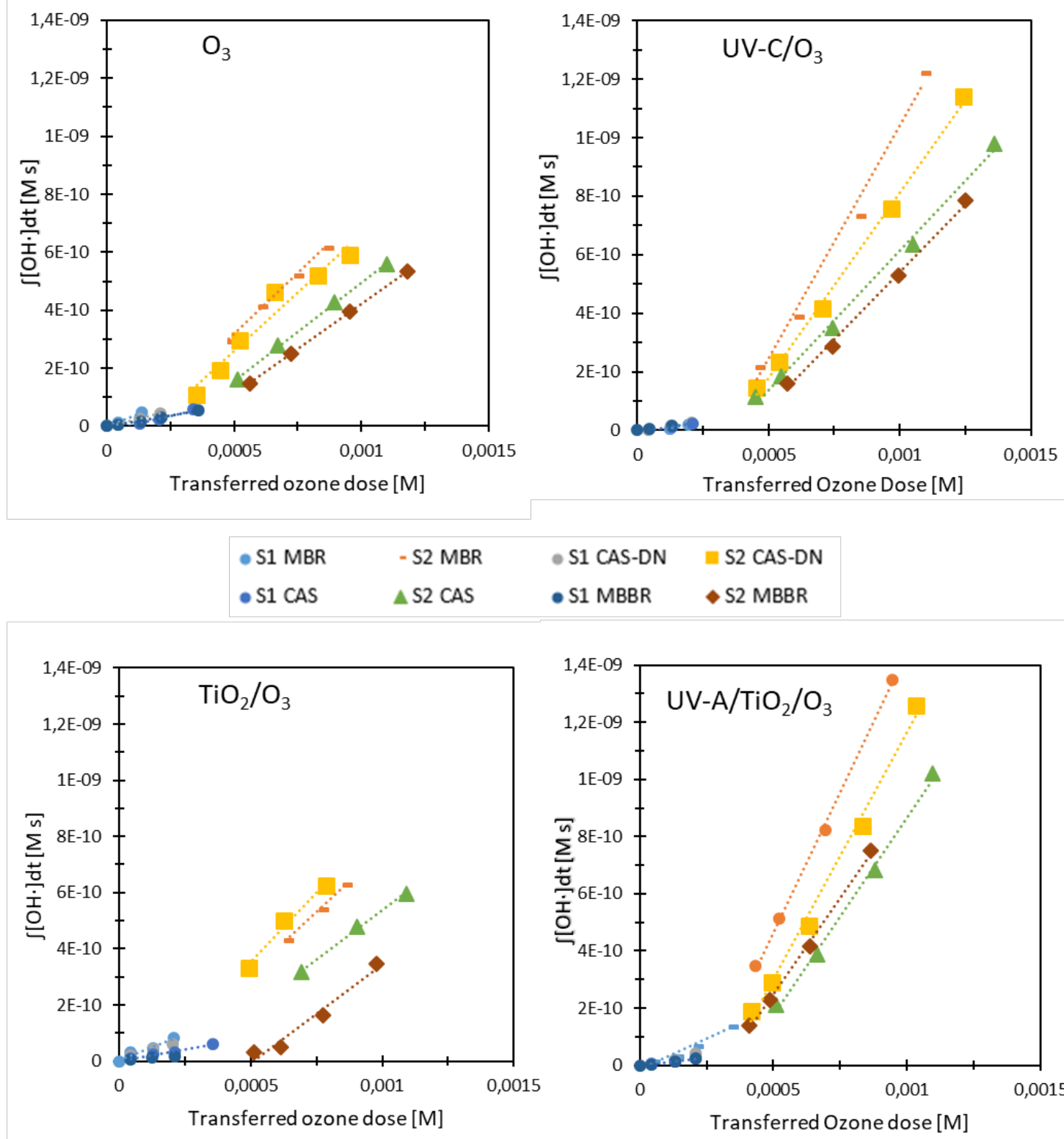

361

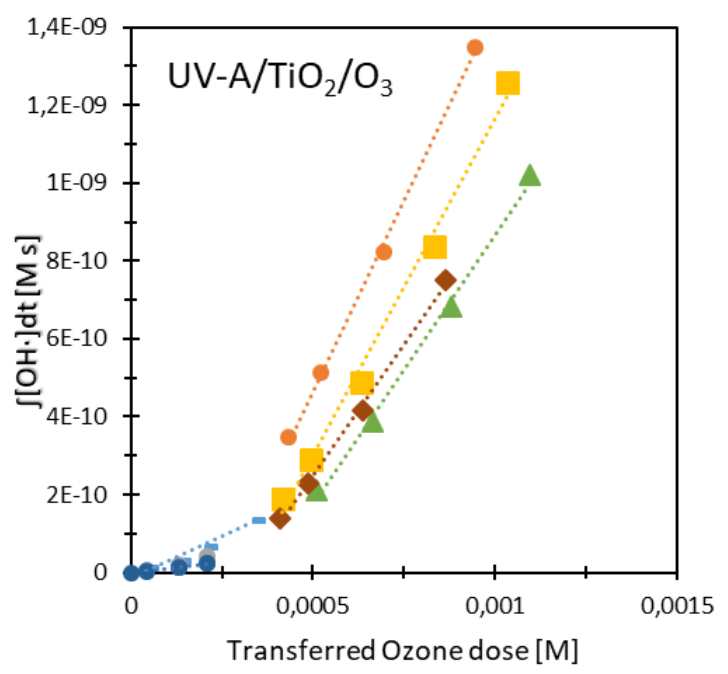

Figure 2. $\mathrm{R}_{\text {Оноз }}$ plots for all experiments. Gas flow rate $=0.3 \mathrm{~L} \mathrm{~min}^{-1}$; Inlet (g) ozone concentration $=10$ mg $\mathrm{O}_{3} \mathrm{~L}^{-1} ; \mathrm{T}_{\text {reaction }}=20 \pm 2{ }^{\circ} \mathrm{C} ; \mathrm{T}_{\text {in }}$ (gas) $=22 \pm 2{ }^{\circ} \mathrm{C} ; \mathrm{P}_{\text {in }}$ (gas) $=25 \pm 2$ mbar.

The results confirm that $\mathrm{RoHO3} \mathrm{is} \mathrm{an} \mathrm{important} \mathrm{parameter} \mathrm{to} \mathrm{determine} \mathrm{the}$ availability of hydroxyl radical on each wastewater matrix, being useful to compare radical production for each process and wastewater tested. It can also be used to predict the amount of TOD required for degrading ozone-resistant micropollutants during 
ozonation (equation 11) [35, 36]. Last assays were performed to evaluate the application of 2 stage Rоноз values of MBR effluent for the prediction of atrazine removal. This pesticide presents low reactivity towards ozone, with second-order rate constant of $6 \mathrm{M}^{-}$ ${ }^{1} \mathrm{~S}^{-1}$ and high reactivity with hydroxyl radicals $\left(k \cdot \mathrm{OH}\right.$ of $\left.3.0 \cdot 10^{9} \mathrm{M}^{-1} \mathrm{~s}^{-1}\right)$ [33]. Plots of the predicted and experimental atrazine abatement in ozonation and photocatalytic ozonation are presented in Figure S12. In both cases, a good agreement between model predictions and experimental measurements was observed. Further experiments should be performed with different micropollutants for its final validation.

\section{Conclusions}

In this work, UV light-assisted ozonation processes attained higher degradation results of recalcitrant and ozone-resistant pesticide acetamiprid than single ozonation on real domestic wastewaters.

More polluted matrices had higher ozone transfer yields due to their reactivity with the oxidant. The presence of UV-C increased ozone consumption mass for all cases reactive compounds towards molecular ozone in all wastewaters. degradation was directly related with the increase in stage two Rоноз values in all 
matrices. On that stage, photolytic ozonation values were up to 54\% higher compared with single ozonation while for photocatalytic ozonation values were higher than double for all wastewaters studied (between 105 to 127\%). These results demonstrate the capacity of light assisted ozonation processes on the enhancement of radical pathway degradation of ozone recalcitrant micropollutants, as well as the usefulness of modified Rоноз parameter on its quantification. To take advantage of the improvements in radical production brought by UV light addition, the adoption of higher $\mathrm{O}_{3}$ doses than the values typically used for ozonation in WWTPs is required.

\section{Acknowledgments}

This Special Issue is dedicated to honor the retirement of Prof. César Pulgarin at the Swiss Federal Institute of Technology (EPFL, Switzerland), a key figure in the area of Catalytic Advanced Oxidation Processes. This work was financially supported by the Spanish Ministry of Economy and Competitiveness (project CTQ2014-52607-R), AGAUR - Generalitat de Catalunya (project 20145GR245). This work was funded by the European Commission within the Erasmus+ KA1 Programme, Erasmus Mundus Joint Master Degree in Chemical Innovation and Regulation.

\section{Bibliography}

[1] Y. Luo, W. Guo, H. Ngo, L. Nghiem, F. Hai, J. Zhang, S. Liang, W. Wang, A review on the occurrence of micropollutants in the aquatic environment and their fate and removal during wastewater treatment, Sci. Total Environ. 473-474 (2014) 619-641. https://doi.org/10.1016/j.scitotenv.2013.12.065. 
416 [2] M. Kim, K. Zoh, Occurrence and their removal of micropollutants in water

417 environments, Environ. Eng. Res. 21:4 (2016) 319-332.

$418 \quad$ https://doi.org/10.4491/eer.2016.115.

419 [3] S. Kurwadkar, X. Zhang, D. Ramirez, F. Mitchell, Emerging Micro-Pollutants in the

420 Environment: Occurrence, Fate, and Distribution, ACS Symposium Series (2015)

421 American Chemical Society: Washington, DC.

422 [4] B. Kasprzyk-Hordern, R. Dinsdale, A. Guwy, The Occurrence of Pharmaceuticals, 423 Personal Care Products, Endocrine Disruptors and Illicit Drugs in Surface Water in South 424 Wales, $\quad$ Water $\quad$ Res. $\quad 42: 13 \quad$ (2008) 3498-3518. 425 https://doi.org/10.1016/j.watres.2008.04.026.

426 [5] K. Fent, A.A. Weston, D. Carminada, Ecotoxicology of human pharmaceuticals, 427 Aquat. Toxicol. 76 (2006) 122-59. https://doi.org/10.1016/j.aquatox.2005.09.009

428 [6] A. Mecha, M. Onyango, M. Momba, Impact of ozonation in removing organic 429 micropollutants in primary and secondary municipal wastewater, Effect of processes 430 parameters. Water $\quad$ Sci. Technol. 74:3 (2016) 756-765. 431 https://doi.org/10.2166/wst.2016.276.

[7] J. Reungoat, B. Escher, M. Macova, F. Argaud, W. Gernjak, J. Keller, Ozonation and biological activated carbon filtration of wastewater treatment plant effluents, Water Res. 46:3 (2012) 863-872. https://doi.org/10.1016/j.watres.2011.11.064.

435 [8] D. Gerrity, S. Gamage, J.C. Holady, D.B. Mawhinney, O. Quiñones, R.A. Trenholm, 436 S. Snyder, Pilot-scale evaluation of ozone and biological activated carbon 632 for trace 437 organic contaminant mitigation and disinfection, Water Res. 45 (2011) 2155-2165. $438 \quad$ https://doi.org/10.1016/10.1016/j.watres.2010.12.031. 
439 [9] U. von Gunten, Ozonation of drinking water: Part I. Oxidation kinetics and product 440 formation, Water Res. 37 (2003) 1443-1467. https://doi.org/10.1016/S0043$441 \quad$ 1354(02)00457-8.

442 [10] M. Bourgin, B. Beck, M. Boehler, E. Borowska, J. Fleiner, E. Salhi, R. Teichler, U. 443 von Gunten, H. Siegrist, C.S. McArdell, Evaluation of a full-scale wastewater treatment 444 plant upgraded with ozonation and biological post-treatments: Abatement of 445 micropollutants, formation of transformation products and oxidation by-products, Water Res. 129 (2018) 486-498. https://doi.org/10.1016/J.WATRES.2017.10.036.

447 [11] P. Stathatou, F. Gad, E. Kampgragou, H. Grigoropoulou, D. Assimacopoulos, 448 Treated Wastewater Reuse potential: mitigating water scarcity problems in the Aegean 449 Islands, Desal. Water Treat. J. 53:12 (2015) 3272-3282. 450 https://doi.org/10.1080/19443994.2014.934108

451 [12] F. Beltran, Ozone Kinetics for Water and Wastewater systems, CRC Press Lewis 452 Publishers, 2004, pp. 193-27.

[13] M. Dodd, M. Buffle, U. von Gunten, Oxidation of antibacterial molecules by aqueous 454 ozone: moiety-specific reaction kinetics and application to ozone-based wastewater 455 treatment, Environ. Sci. Tech. 40 (2006) 1969-1977. https://doi.org/10.1021/es051369x. [14] G.V. Buxton, C.L. Greenstock, W.P. Helman, A.B. Ross, Critical Review of rate constants for reactions of hydrated electrons, hydrogen atoms and hydroxyl radicals in 458 aqueous solution, J. Phys. Chem. Ref. Data 17 (1988) 513-886. 459 https://doi.org/10.1063/1.555805. (accessed 22 April 2018). 

system for reduction of health-care associated pathogens, J. Microbiol. Immunol. Infect. (2017). https://doi.org/10.1016/j.jmii.2017.08.017.

[17] S. Satyro, E. Saggioro, F. Verissimo, D. Buss, D. Paiva Magalhaes, A. Oliveira,

Triclocarban: UV photolysis, wastewater disinfection and ecotoxicology assessment using molecular biomarkers, Environ. Sci. Pollut. Res. Int. 24:19 (2017) 16077-16085. https://doi.org/10.1007/s11356-017-9165-4.

[18] Z. Chen, J. Fang, C. Fan, S. Shang, Oxidative degradation of N-Nitrosopyrrolidine by the ozone/UV process: Kinetics and pathways, Chemosphere 150 (2016) 731-739. https://doi.org/10.1016/j.chemosphere.2015.12.046.

[19] D. Robert, R. Daghirt, P. Drogui, Modified $\mathrm{TiO}_{2}$ For Environmental Photocatalytic Applications: A Review, Ind. Eng. Chem. Res. 52:10 (2013) 3581-3599. https://doi.org/10.1021/ie303468t.

[20] I. Ola, M. Maroto-Valer, Review of material design and reactor engineering on $\mathrm{TiO}_{2}$ photocatalysis for $\mathrm{CO}_{2}$ reduction, J. Photochem. Photobiol. C- Photochem. Rev. 24

477 (2015) 16-42. https://doi.org/10.1016/j.jphotochemrev.2015.06.00.

[21] J. Carbajo, A. Bahamonde, M. Faraldos, Photocatalyst performance in wastewater treatment applications: Towards the role of $\mathrm{TiO}_{2}$ properties. Mol. Catal. 434 (2017) 167174. https://doi.org/10.1016/j.mcat.2017.03.018.

481 [22] A. Lisenbigler, G. Lu, J. Yates, Photocatalysis on $\mathrm{TiO}_{2}$ Surfaces: Principles,

Mechanisms, and Selected Results, Chem. Rev. $95 \quad$ (1995) 735-758. https://doi.org/10.1021/cr00035a013. 
484 [23] Y. Guo, L. Yang, X. Cheng, X. Wang, The Application and Reaction Mechanism of

485 Catalytic Ozonation in Water Treatment, J. Environ. Anal. Toxicol. 2:150 (2012). 486 https://doi.org/10.4172/2161-0525.1000150.

487 [24] E. Emam, Effect of ozonation combined with heterogeneous catalysts and ultraviolet 488 radiation on recycling of gas-station wastewater, Egypt. J. Petrol, 21:1 (2012) 55-60. 489 https://doi.org/10.1016/j.ejpe.2012.02.008.

[25] K.P. Yu , G. Whei-May Lee, G.H. Huang, The Effect of Ozone on the Removal 491

Effectiveness of Photocatalysis on Indoor Gaseous Biogenic Volatile Organic

492 Compounds, J. Air Waste Manag. Assoc. 60:7 (201) 820-829. 493 https://doi.org/10.3155/1047-3289.60.7.820. of ozonation and photocatalysis for purification of aqueous effluents containing formic acid as probe pollutant and bromide ion, Water Res. 50 (2014) 189-199. https://doi.org/10.1016/j.watres.2013.12.001.

[27] F. Beltran, A. Aguinaco, J. Garcia-Araya, Kinetic modelling of TOC removal in the photocatalytic ozonation of diclofenac aqueous solutions Appl. Catal. B: Environ. 100:12 (2010) 289-298. https://doi.org/10.1016/j.apcatb.2010.08.005.

[28] O. Eren, E. Kusvuran, A. Yildirim, S.A. Gul, Comparative Study of Ozonation, Homogeneous Catalytic Ozonation, and Photocatalytic Ozonation for C.I. Reactive Red 194 Azo Dye Degradation, Clean soil air water. 39:8 (2011) 795-805.

504 https://doi.org/10.1002/clen.201000192. 
507 UV/Ozonation Processes, J. Adv. Oxid. Technol. 12:2 (2009) 208-214.

508 https://doi.org/10.1515/jaots-2009-0209.

509 [30] R. Solis, F. Rivas, J. Perez-Bote, O. Gimeno, Photocatalytic ozonation of 4-chloro-

510 2-methylphenoxyacetic acid and its reaction intermediate 4-chloro-2-methyl phenol, J.

511 Taiwan $\quad$ Inst. $\quad$ Chem. $\quad$ Engin. $46 \quad$ (2015) 125-131.

512 https://doi.org/10.1016/j.jtice.2014.09.010.

513 [31] O. Gimeno, F. Rivas, F. Beltran, M. Carbajo, Photocatalytic Ozonation of Winery

514 Wastewaters, J.Agric. Food. Chem, 55:24 (2007) 9944-9950.

$515 \quad$ https://doi.org/10.1021/jf072167i.

516 [32] N. Moreira, J. Sousa, G. Macedo, A. Ribeiro, L. Barrieros, M. Pedrosa, J. Faria, M.

517 Pereira, S. Castro-Silva, M. Segundo, C. Manaia, O. Nunes, A. Silva, Photocatalytic 518 ozonation of urban wastewater and surface water using immobilized $\mathrm{TiO}_{2}$ with LEDs:

519 Micropollutants, antibiotic resistance genes and estrogenic activity, Water Res. 94 (2016)

520 10-22. https://doi.org/10.1016/j.watres.2016.02.003.

521 [33] J. Acero, K. Stemmler, U. von Gunten, Degradation Kinetics of Atrazine and its

522 degradation products with ozone and $\mathrm{OH}$ radicals: a predictive tool for drinking water 523 treatment, Environmental Sci. Tech. $34 \quad$ (2000) 591-597. 524 https://doi.org/10.1021/es990724e.

525 [34] M.S. Elovitz, U. von Gunten, Hydroxyl Radical/ Ozone Ratios During Ozonation 526 Processes. I. The Rct Concept, Ozone Sci. Eng. 21:3 (1999) 239-260. 527 https://doi.org/10.1080/0191951990854723.

528 [35] M. Kwon, H. Kye, Y. Jung, Y. Yoon, H. Kang, Performance characterization and 529 kinetic modeling of ozonation using a new method: Rоноз concept, Water Res. 122 (2017) 530 p 172-182. https://doi.org/10.1016/j.watres.2017.05.062. 
531 [36] A. Cruz-Alcalde, S. Esplugas, C. Sans, Abatement of ozone-recalcitrant 532 micropollutants during municipal wastewater ozonation: kinetic modelling and surrogate533 based control strategies, Chem. Eng. J. In press. 534 https://doi.org/10.1016/j.cej.2018.10.206.

535 [37] S. Canonica, L. Meunier, U. von Gunten, Phototransformation of selected 536 pharmaceuticals during UV treatment of drinking water, Water Res. 42 (2008) 121-128. 537 https://doi.org/10.1016/j.watres.2007.07.026.

538 [38] M. Marce, B. Domenjoud, S. Esplugas, S. Baig, Ozonation treatment of urban 539 primary and biotreated wastewaters: Impacts and modeling, Chem. Eng. J. 283 (2016) 540 768-777. https://doi.org/10.1016/j.cej.2015.07.073.

541 [39] A. Cruz-Alcalde, C. Sans, S. Esplugas, Priority pesticide abatement by advanced 542 water technologies: the case of acetamiprid removal by ozonation, Sci, Total Environ. 543 599-600 (2017) 1454-1461. http://dx.doi.org/10.1016/j.scitotenv.2017.05.065.

544 [40] D. Gardoni, R. Canziani, Decay of ozone in water: a review, Ozone Sci. Eng. 34:4 545 (2012) 233-242. https://doi.org/10.1080/01919512.2012.686354.

546 [41] A. Yavas, Catalytic ozonation of paracetamol using commercial and Pt-supported 547 nanocomposites of $\mathrm{Al}_{2} \mathrm{O}_{3}$ : The impact of ultrasound, Ultrason. Sonochem. 40 (2018) 175548 182. https://doi.org/10.1016/j.ultsonch.2017.02.017.

549 [42] R. Zhang, D. Yuan, B. Liu, Kinetics and products of ozonation of C.I. Reactive Red 550195 in semi-batch reactor, Chin. Chem. Lett. 26:1 (2015) 93551 99. https://doi.org/10.1016/j.cclet.2014.10.024.

552 [43] W. Audenaert, Y. Vermeersch, Y. Van Hulle, P. Dejans, A. Dumoulin, I. Nopens, 553 Application of a mechanistic UV/hydrogen peroxide model at full scale: sensitivity 
554 analysis, calibration and performance evaluation, Chem. Eng. J. 171:1 (2011) 113-126.

$555 \quad$ https://doi.org/10.1016/j.cej.2011.03.071.

556 [44] P. Andersen, C. Williford, J. Birks, Miniature personal ozone monitor based on UV

557 Absorbance, Anal. Chem. 82:19 (2010) 7924-7928. https://doi.org/10.1021/ac1013578.

558 [45] S. Gora, S. Andrews, Adsorption of natural organic matter and disinfection 559 byproduct precursors from surface water onto $\mathrm{TiO}_{2}$ nanoparticles: $\mathrm{pH}$ effects, isotherm 560 modelling and implications for using $\mathrm{TiO}_{2}$ for drinking water treatment, Chemosphere 561174 (2017) 363-370. https://doi.org/10.1016/j.chemosphere.2017.01.125. 